\section{Freezing Tolerance and Cold Acclimation in Guava \\ (Psidium guajava L.)}

\author{
Wei Hao and Rajeev Arora ${ }^{1}$ \\ Department of Horticulture, Iowa State University, 139 Horticulture Hall, \\ Ames, IA 50011-1100
}

\author{
Anand K. Yadav and Nirmal Joshee \\ Agricultural Research Station, Fort Valley State University, Fort Valley, \\ GA 31030-4313
}

Additional index words. freezing stress, woody perennial, dehydrins, 'Lucknow-49', 'Ruby $\times$ Supreme'

\begin{abstract}
Guava (Psidium guajava L.) is a tropical evergreen tree that tolerates a wide range of frost-free environments. In recent years, the American market demand for exotic and nutritious fruits, like guava, has been increasing, and, with a long harvest period, guava can be a potential alternative, high-value cash crop in the United States. However, the major limitation with commercializing guava cultivation in the United States is its low cold tolerance. In this article, we studied the physiology of freezing tolerance and cold acclimation in guava. Laboratory freeze-thaw tests (on leaves), shoot growth and leaf relative water content measurements, leaf anthocyanin content analyses, and leaf protein analyses were performed on nonacclimated and cold-acclimated guava cultivars Lucknow-49 and Ruby $\times$ Supreme. The leaf freezing tolerance (expressed as $\mathrm{LT}_{50}$ values) of nonacclimated tissues was $\approx-2.5{ }^{\circ} \mathrm{C}$ and significantly enhanced to $\approx-4.4^{\circ} \mathrm{C}$ after an environmentally controlled cold acclimation regime for both cultivars. However, when compared based on actual injury sustained by leaves at various freezing temperatures in a freeze-thaw test, 'Ruby $\times$ Supreme' exhibited significantly less injury than 'Lucknow-49' at most temperatures. Growth and leaf relative water content reduced, whereas leaf anthocyanins accumulated during cold acclimation. Leaf protein analyses, which were performed after cold acclimation and drought stress, revealed that four proteins $(69,48,23.5$, and $17.4 \mathrm{kDa})$ accumulated in response to low temperatures, and two proteins (17.4 and $16 \mathrm{kDa})$ accumulated in response to drought stress. Antidehydrin immunoblots revealed that one common $17.4 \mathrm{kDa}$ dehydrin accumulated in response to cold and drought stresses. Our data indicate that guava possesses leaf freezing tolerance, exhibits cold acclimation ability, and that 'Ruby $\times$ Supreme' leaves are relatively more freezing-tolerant than 'Lucknow- 49 ' when compared up to -4 and -8 ${ }^{\circ} \mathrm{C}$ for nonacclimated and cold-acclimated tissues, respectively. Cold acclimation in guava appears to be a multifactorial process involving complex physiological and biochemical changes and also overlapping responses with drought stress.
\end{abstract}

Cold and drought stresses are acknowledged to be the two most dominant environmental stresses that affect the growth, productivity, and distribution of crops and

Received for publication 6 Jan. 2009. Accepted for publication 18 Feb. 2009.

Financial support from the Specialty Fruit Biotechnology Program at Fort Valley State University, Fort Valley, GA (through a USDA-CSREES guava research project 2004-02595, award number 2004-38814-15128 to A.K.Y.), and College of Agriculture and Life Sciences at Iowa State University (to R.A.) is gratefully acknowledged.

We thank Dr. Williams Graves (Department of Horticulture, Iowa State University) for kindly providing the pressure bomb and training with the equipment. We also thank Arlen Patrick (greenhouse manager, Department of Horticulture, Iowa State University) for support and help with plant care throughout this study.

${ }^{1}$ To whom reprint requests should be addressed; e-mail rarora@iastate.edu. freezing tolerance of plants increases after exposure to low, nonfreezing temperatures (Thomashow, 1999). Almost all temperate perennials and many annual and biennial plants can alter their freezing tolerance when exposed to low, nonfreezing temperatures (Wisniewski et al., 2003). CA is a complex process associated with physiological and biochemical changes in the plants, including modifications in membrane lipid composition; increases in soluble sugars, amino acids, and organic acids; synthesis and accumulation of antioxidants and protective proteins; changes in hormone levels; and alterations in gene expression (Thomashow, 1999; Xin and Browse, 2000).

Numerous electrophoretic studies have reported both quantitative and qualitative differences in protein content between nonacclimated and cold-acclimated tissues (Arora et al., 1992; Guy and Haskell, 1988; Wisniewski et al., 1996); most notable among these are dehydrin proteins (Lea D II family) (Arora and Wisniewski, 1994; Bassett et al., 2006; Muthalif and Rowland, 1994; Peng et al., 2008; Wisniewski et al., 1999). Dehydrins are encoded by a multigene family and accumulate in response to environmental stresses that lead to dehydration such as low temperature, drought, and high salinity (Close, 1997). Previous studies imply that the dehydrins may stabilize cellular structure during dehydration stress (Close, 1997; Danyluk et al., 1998; Peng et al., 2008; Rinne et al., 1999).

Guava (Psidium guajava L.), which belongs to the Myrtaceae family, is a small evergreen tree (Morton, 1987a; Yadava, 1996). Guava can tolerate a wide range of frost-free environments and flourishes in both humid and dry climates at elevations between sea level and $2100 \mathrm{~m}$ (Yadava, 1996). It exceeds most of the tropical and subtropical fruit trees in adaptability as a result of its chilling, drought, and salinity tolerance and can produce fruits continuously throughout the year in climates suitable for production (Yadava, 1996).

In recent years, the American market demand for exotic fruits, like guava, has been increasing, mainly because of increased immigration from Asia, Latin America, and other warm-climate countries (Yadava, 1996). With a long harvest period, guava can be a potential alternative, high-value cash crop in the United States (Yadava, 1996). Guava plants are cultivated in many countries, including India, Brazil, South Africa, Venezuela, Cuba, the Philippines, and New Zealand (Hawaii Agricultural Statistics Service, 1999); however, the majority of guava cultivation in the United States is limited only to a few favorable locations in California, Florida, and Hawaii (Yadava, 1996). The major limitation with expanding guava cultivation to further north in the United States is its low cold tolerance (Yadava, 1996). Yet, research on the freezing tolerance and $\mathrm{CA}$ ability of guava has received little attention. An understanding of the biology of freezing tolerance and $\mathrm{CA}$ in guava may provide the 
basis for potential frost-protection strategies and developing freezing-tolerant cultivars and may also trigger interest in the responses of other tropical and subtropical plants to cold stress.

We used two highly productive guava cultivars, Lucknow-49 and Ruby $\times$ Supreme (Morton, 1987a), in this study to examine the physiology of freezing tolerance in guava. The major objectives were 1) to determine whether guava, which is native to the tropics, possesses any freezing tolerance; 2) to determine whether freezing tolerance of guava can be enhanced by an environmentally controlled CA regime; and 3) to investigate the physiological changes such as growth, leaf water content, proteins, and so on, associated with CA.

\section{Materials and Methods}

Plant materials and growth conditions. Bulked seed collected from self-pollinations of 'Lucknow-49' and 'Ruby $\times$ Supreme' were obtained from Fort Valley State University (Fort Valley, GA). Seeds were germinated in Dec. 2006 in plug trays $(52.5 \times$ $26 \times 6 \mathrm{~cm} ; 50$ plugs) with Peat-Lite mix (Sunshine LC1 Mix; Sun Gro Horticulture Ltd., Bellevue, WA) in the greenhouse at the Department of Horticulture, Iowa State University. Three-month-old guava seedlings were transplanted to $21 \times 20 \mathrm{~cm}$ (diameter $\times$ height) plastic pots and maintained in a greenhouse at $24 \pm 2{ }^{\circ} \mathrm{C}$ with a natural photoperiod. The plants were fertilized and irrigated as needed.

Cold acclimation treatment. Three uniform 1-year-old plants (nonacclimated) of each cultivar were chosen randomly and transferred to a growth chamber for 4 weeks with a 15-h photoperiod under cool-white fluorescent lamps that provided photosynthetically active radiation of $60 \pm 4$ $\mu \mathrm{mol} \cdot \mathrm{m}^{-2} \cdot \mathrm{s}^{-1}$. Plants were exposed to a stepwise lowering of temperatures in the growth chamber as follows: $18 / 12{ }^{\circ} \mathrm{C}$ (day/night) for 1 week, then $15 / 9{ }^{\circ} \mathrm{C}$ (day/night) for 1 week, then $10 / 5{ }^{\circ} \mathrm{C}$ (day/night) for 1 week, and finally $7 / 3{ }^{\circ} \mathrm{C}$ (day/night) for 1 week. Another three uniform nonacclimated plants of each cultivar were maintained at $24 \pm 2{ }^{\circ} \mathrm{C}$ in the greenhouse for 4 weeks as a control for growth analysis. This 4 -week CA treatment was repeated three times in the same growth chamber for three independent experiments. Here, we present data from one such representative experiment.

Leaf water content and growth analysis. Growth parameters were measured for nonacclimated (control) and cold-acclimated plants before and during three repeated CA experiments. In each experiment, fresh weight, saturated fresh weight, and dry weight of leaves were determined for each cultivar. After measuring the fresh weight of freshly harvested leaves, they were placed into containers with distilled, deionized water for 24 to $30 \mathrm{~h}$ to a constant weight and saturated fresh weight was measured for each sample. Dry weight was obtained after drying these leaves at $70{ }^{\circ} \mathrm{C}$ in an oven for 48 to $72 \mathrm{~h}$ to a constant weight. In all measurements, fully expanded leaves of a similar age were used. Leaf relative water content was calculated as (leaf fresh weight - leaf dry weight)/ (leaf saturated - fresh weight - leaf dry weight)*100 (Peng et al., 2007).

Shoot elongation was determined by measuring the distance between a reference mark and the shoot tip before and during CA treatments. The reference marking was made between the shoot tip and the first node with a piece of red thread before CA treatment. Measurements were made on three plants per cultivar for nonacclimated and coldacclimated treatments.

Leaf freezing tolerance. Leaf freezing tolerance (LFT) was determined by measuring changes in electrical conductivity (EC) of freeze-thawed tissue (Palta et al., 1977) using the method described by Lim et al. (1998). The freezing tolerance of nonacclimated leaves was performed on the same day before the plants were transferred to the growth chamber for CA, whereas cold-acclimated leaves were evaluated for LFT at the end of the CA treatment. Leaves of similar age were sampled from three plants from each cultivar and cut into discs $1.9 \mathrm{~cm}$ in diameter. Three discs for each treatment temperature of each cultivar were placed separately into test tubes $(200 \times 25 \mathrm{~mm}, 70$ $\mathrm{mL}$ ) containing $100 \mu \mathrm{L}$ distilled, deionized water. Test tubes with leaf discs were placed in a glycol bath (Model 3028; Fisher Scientific Inc., Pittsburgh, PA) for freezing treatment. Treatment temperatures were $-0.5,-1$, $-1.5,-2,-2.5,-3,-3.5$, and $-4{ }^{\circ} \mathrm{C}$ for nonacclimated plants and $-0.5,-1,-1.5,-2,-2.5$, $-3,-3.5,-4,-5,-6,-7$, and $-8{ }^{\circ} \mathrm{C}$ for coldacclimated plants. Three unfrozen discs of each cultivar were placed at $0{ }^{\circ} \mathrm{C}$ on ice as the control. Samples in the glycol bath were icenucleated with an ice chip at $-0.5{ }^{\circ} \mathrm{C}$ and equilibrated for $1 \mathrm{~h}$. Thereafter, samples were cooled at the rate of $0.5^{\circ} \mathrm{C}$ every $30 \mathrm{~min}$ to $-4{ }^{\circ} \mathrm{C}$ (nonacclimated plants) and subsequently at the rate of $1{ }^{\circ} \mathrm{C}$ every $40 \mathrm{~min}$ to $-8{ }^{\circ} \mathrm{C}$ (cold-acclimated plants). Tubes were removed from the glycol bath at each treatment temperature, first placed in ice for overnight thaw, and then transferred to $4{ }^{\circ} \mathrm{C}$ for $1 \mathrm{~h}$. Samples were then incubated for $1 \mathrm{~h}$ at room temperature. Subsequently, $20 \mathrm{~mL}$ of distilled, deionized water was added to each tube and samples were vacuum-infiltrated at $\approx 100 \mathrm{kPa}$ for $3 \mathrm{~min}$ and then shaken at 250 $\mathrm{rpm}$ on a platform shaker (Model Innova 2300; New Brunswick Scientific Co. Inc., Edison, NJ) for $1.5 \mathrm{~h}$. EC of the leachate was measured with a conductivity instrument (Model 3100; YSI Inc., Yellow Springs, $\mathrm{OH})$ at room temperature before [initial EC (IEC)] and after [final EC (FEC)] leaf discs were autoclaved at $121^{\circ} \mathrm{C}$ for $20 \mathrm{~min}$ with a slow exhaust cycle of $7.56 \mathrm{~g} \cdot \mathrm{s}^{-1}$. Percentage ion leakage $(\% \mathrm{IL})$ was calculated as the ratio of IEC to FEC and percentage injury (\% injury) was calculated as follows: $\%$ injury $y_{t}=$ $\left(\% \mathrm{IL}_{\mathrm{t}}-\% \mathrm{IL}_{\mathrm{c}}\right) /\left(100-\% \mathrm{IL}_{\mathrm{c}}\right) * 100$. Here, $\% \mathrm{IL}_{\mathrm{t}}$ and $\% \mathrm{IL}_{\mathrm{c}}$ represent percentage ion leakage of each treatment temperature and control, respectively (Lim et al., 1998). $\mathrm{LT}_{50}$, the temperature at which $50 \%$ injury occurred, was defined as LFT and $50 \%$ injury level was calculated as follows: ( $\%$ injury $_{\max }$ $+\%$ injury $\left._{\min }\right) / 2$, where $\%$ injury $_{\max }=$ the maximum percent injury and $\%$ injury $_{\min }=$ the minimum percent injury (Sutinen et al., 1992). $\mathrm{LT}_{50}$ was estimated by fitted sigmoidal curves with Gompertz function (Lim et al., 1998).

Leaf anthocyanin analysis. Leaf relative anthocyanin contents were determined following the protocols described in Neff and Chory (1998) and Kleine et al. (2007). In brief, $0.1 \mathrm{~g}$ leaf tissue powder was incubated overnight in $300 \mu \mathrm{L}$ acidified methanol $(1 \%$ $\mathrm{HCl})$. The next day, anthocyanin was separated from chlorophyll by adding $200 \mu \mathrm{L}$ distilled, deionized water and $500 \mu \mathrm{L}$ chloroform. Absorbance at $530 \mathrm{~nm}$ and $657 \mathrm{~nm}$ of the aqueous phase was determined using a spectrophotometer (Model DU-640; Beckman Coulter, Inc., Fullerton, CA). The relative anthocyanin contents per fresh weight were calculated as: $\mathrm{A}_{657}-0.25 \times \mathrm{A}_{530}$ by compensating the contribution of chlorophyll and its degradation products to the absorbance of anthocyanins. $1 \% \mathrm{HCl}$ methanol was used as the blank absorbance.

Drought stress treatment and water potential measurement. Four uniform, wellwatered, 18-month-old plants were chosen from each cultivar. They were subjected to drought stress by withholding watering until wilting was observed and then allowing them to recover by resuming irrigation. The fully expanded youngest leaf with petiole was cut from each plant before the drought stress treatment (control), every 2 or $3 \mathrm{~d}$ during the water deficit, and finally during the recovery, and immediately after leaf collection at 0900 HR, water potential $\left(\Psi_{\text {leaf }}, \mathrm{MPa}\right)$ was measured using a pressure bomb (Model 670; P.M.S. Instrument Company, Albany, OR). Control and drought-stressed leaves were freeze-dried by liquid nitrogen and stored at $-80{ }^{\circ} \mathrm{C}$ for subsequent protein analysis.

Leaf protein extraction and measurement. Leaf proteins were extracted by the method described by Gaspar et al. (1997) with minor modifications. Leaves from nonacclimated and cold-acclimated, well-watered (control), drought-stressed (20 and $18 \mathrm{~d}$ of water deficit for 'Lucknow-49' and 'Ruby $\times$ Supreme', respectively) and drought stress-recovered ( $5 \mathrm{~d}$ of recovery) plants were collected, lyophilized, and ground to a fine powder. A total of $0.3 \mathrm{~g}$ powder of each sample was washed at $4{ }^{\circ} \mathrm{C}$ with $20 \mathrm{~mL}$ solution (methanol:acetic acid:water $=10: 1: 9$ ) and spun at $20,000 \times g$ for $30 \mathrm{~min}$. The pellet was then washed with $15 \mathrm{~mL}$ hexane and $15 \mathrm{~mL}$ acetone consecutively at $4{ }^{\circ} \mathrm{C}$. The supernatant was discarded and the pellet was dried for a few hours at room temperature. Dry pellet was then treated with $1.5 \mathrm{~mL}$ extraction buffer $[80 \mathrm{~mm}$ Tris- $\mathrm{HCl}$ buffer $(\mathrm{pH}$ 6.8), $0.1 \mathrm{M} \beta$-mercaptoethanol, 2\% (w/v) SDS, and $15 \%(\mathrm{v} / \mathrm{v})$ glycerol] and immediately heated at $100{ }^{\circ} \mathrm{C}$ for $10 \mathrm{~min}$. The samples were 
stored at $4{ }^{\circ} \mathrm{C}$ overnight after being cooled to room temperature. The next day, samples were centrifuged at $15,800 \times g$ for $30 \mathrm{~min}$, yielding supernatant as the source of leaf tissue protein for sodium dodecyl sulfate polyacrylamide gel electrophoresis (SDS-PAGE).

Protein concentration was determined by a modification of the Esen protein assay (Esen, 1978). Equal aliquots (5 $\mu \mathrm{L}$; triplicates) from various extractions and BSA standards ( 0 to $4 \mathrm{mg} \cdot \mathrm{mL}^{-1}$; triplicates) were spotted on Whatman No. 1 chromatography paper and stained with $0.1 \%$ Coomassie brilliant blue dye R-250. After rinsing briefly with water and drying, the stained spots were eluted with $1 \%$ SDS and absorbance of the dye-protein complex was measured at $600 \mathrm{~nm}$.

SDS-PAGE and immunoblotting. Samples with equal amounts of protein $(12 \mu \mathrm{g})$ were subjected to SDS-PAGE and visualized by Coomassie stain as described in Arora et al. (1992). In brief, discontinuous SDS-PAGE was performed with a PROTEAN II electrophoresis unit (Bio-Rad Laboratories, Inc., Hercules, CA) using 4\% stacking gel and a $12.5 \%$ separating gel. Gels were stained by Brilliant blue G-Colloidal (Sigma-Aldrich Co., St. Louis, MO). Band intensities on SDS-PAGE were estimated using visual observations and densitometry (Quantity One 1-D Analysis Software; Bio-Rad Laboratories, Inc.).

For immunoblots, separated proteins (4 $\mu \mathrm{g}$ ) from an unstained gel were transferred to nitrocellulose membranes as described in Arora and Wisniewski (1994). Membranes were probed at 1:500 dilution with antidehydrin antibody (kindly provided by Dr. Timothy Close) directed against a synthetic peptide of a 15 residue consensus sequence (EKKGIMDKIKEKLPG), which is highly conserved at the C-terminus of dehydrin proteins (Close et al., 1993). Immunoreactive bands were detected by alkaline phosphatase assay using the ProtoBlot Western Blot AP Kit (Promega Corp., Madison, WI).

Statistical analysis. Results were expressed as mean values \pm SE. Comparisons between cultivars and treatment means, using a significance level of $P<0.05$, were performed using the two-way analysis of variance of the Statistical Analysis System (SAS) software (SAS Institute Inc., Cary, NC).

\section{Results}

Effect of cold acclimation on growth and anthocyanins. Shoot elongation of both guava cultivars was reduced by the CA treatment, significantly for 'Lucknow-49', whereas moderately for 'Ruby $\times$ Supreme' (Fig. 1A). Daily elongation rates (final shoot elongation/days) of cold-acclimated plants were less than that of nonacclimated plants, and shoots of 'Lucknow-49' elongated more than shoots of 'Ruby $\times$ Supreme' for both nonacclimated (significantly) and cold-acclimated plants (moderately). Mean elongation rates of nonacclimated plants were $374 \pm 69$ and $172 \pm 17 \mathrm{~nm} \cdot \mathrm{d}^{-1}$ in 'Lucknow-49' and

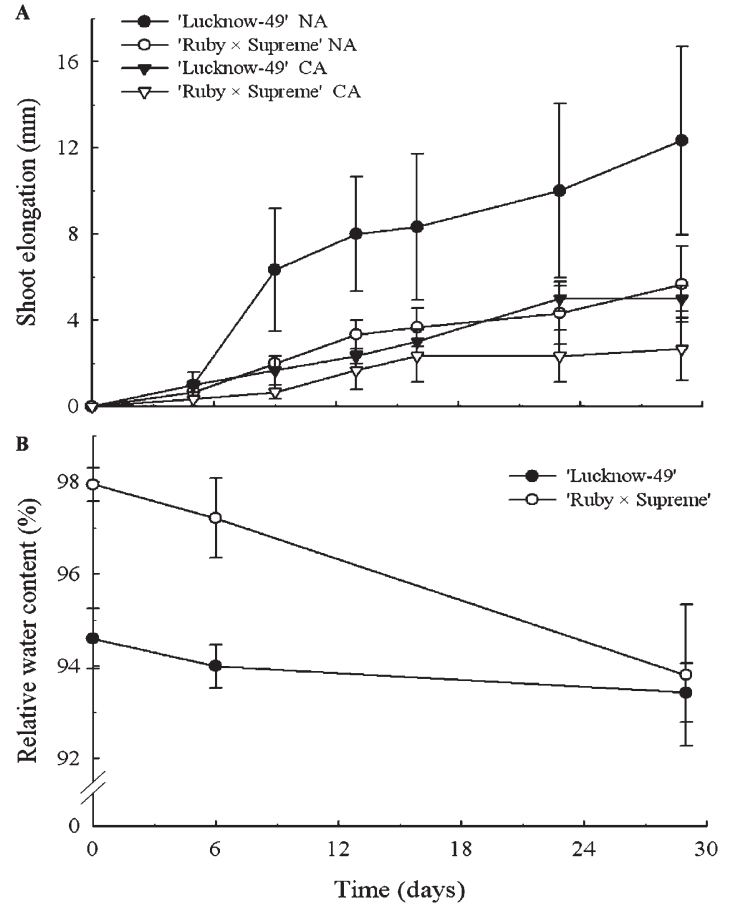

Fig. 1. Growth analysis of Psidium guajava L. 'Lucknow-49' and 'Ruby $\times$ Supreme' on (A) shoot elongation in nonacclimation (NA) and cold acclimation (CA) regimes and (B) changes of relative leaf water content from NA regime $(0 \mathrm{~d})$ to 28 -d CA regime. Values are means \pm SE of three replicates.

'Ruby $\times$ Supreme', respectively, whereas for cold-acclimated plants, rates were $152 \pm 10$ and $81 \pm 22 \mathrm{~nm} \cdot \mathrm{d}^{-1}$, respectively. Leaf relative water content of the two cultivars was reduced after a 28-d CA treatment compared with nonacclimation (NA) levels, significantly for 'Ruby $\times$ Supreme', whereas nonsignificantly for 'Lucknow-49'. 'Ruby $\times$ Supreme' had significantly higher leaf relative water content in NA state than 'Lucknow-49'; however, it reduced more than 'Lucknow-49' during CA reaching roughly the same level as that of 'Lucknow-49' after $28 \mathrm{~d}$ of CA (Fig. 1B).

After subjecting plants to CA for 4 weeks, a color change from green (nonacclimated leaves) to mostly red in cold-acclimated leaves was visually observed in both cultivars (Fig. 2A). Subsequently, the anthocyanin contents were determined on nonacclimated and cold-acclimated leaves. Cold-acclimated leaves accumulated anthocyanin in both 'Lucknow-49' and 'Ruby $\times$ Supreme' (Fig. 2B). Leaf relative anthocyanin contents increased by fourfold and threefold in 'Lucknow-49' and 'Ruby $\times$ Supreme', respectively, compared with their nonacclimated levels. 'Lucknow-49' had a relatively higher level of anthocyanins than 'Ruby $\times$ Supreme' in both nonacclimated and cold-acclimated plants. Our observations indicate that particularly the older leaves (with or without anthocyanin) of cold-acclimated plants tend to abscise a few days after the plants are moved back to normal growth temperatures, whereas newly emerged leaves (with or without anthocyanin) continued to grow.

Leaf freezing tolerance of nonacclimated and cold-acclimated plants. Freezing toler- ance of leaf tissue from nonacclimated and cold-acclimated cultivars varied with treatment temperatures (Fig. 3). Nonacclimated leaf tissues did not suffer injury when frozen at $-0.5^{\circ} \mathrm{C}$, had minimum injury at $-1{ }^{\circ} \mathrm{C}$, and were incrementally injured with decreasing (more negative) treatment temperatures. 'Lucknow-49' suffered more freezing injury than 'Ruby $\times$ Supreme' at all treatment temperatures. At $-2.5,-3$, and $-3.5{ }^{\circ} \mathrm{C}$, 'Lucknow-49' suffered greater freezing injury (by $29 \%$ or greater) than 'Ruby $\times$ Supreme'. Maximum injuries recorded for nonacclimated leaf tissue were $91 \%$ for 'Lucknow-49' and 70\% for 'Ruby $\times$ Supreme' at $-4{ }^{\circ} \mathrm{C}$. Freezing injury increased gradually with decreasing temperature in both cultivars until $-2.5^{\circ} \mathrm{C}$, after which the injury increased abruptly in both cultivars reaching a plateau at -3.5 and $-4{ }^{\circ} \mathrm{C}$ for 'Lucknow-49', whereas such "leveling-off" response at these temperatures was not apparent for 'Ruby $\times$ Supreme' (Fig. 3A); no significant change in the freezing injury was observed for 'Ruby $\times$ Supreme' beyond $-4{ }^{\circ} \mathrm{C}$ (data not shown).

Both cultivars exhibited CA capacity when exposed to CA treatment. Cold-acclimated leaf tissue showed minimum injury at $-2{ }^{\circ} \mathrm{C}$, whereas maximum injury recorded was $88 \%$ and $79 \%$ at $-8{ }^{\circ} \mathrm{C}$ for 'Lucknow- 49 ' and 'Ruby $\times$ Supreme', respectively. A gradual increase in freezing injury was also seen in both cultivars in the cold-acclimated plants; however, the injury increased abruptly from -4 to $-5{ }^{\circ} \mathrm{C}$ and reached a plateau at -7 and $-8{ }^{\circ} \mathrm{C}$ in both cultivars. 'Lucknow-49' exhibited more injury than 'Ruby $\times$ Supreme' at all but one $\left(-7{ }^{\circ} \mathrm{C}\right)$ 

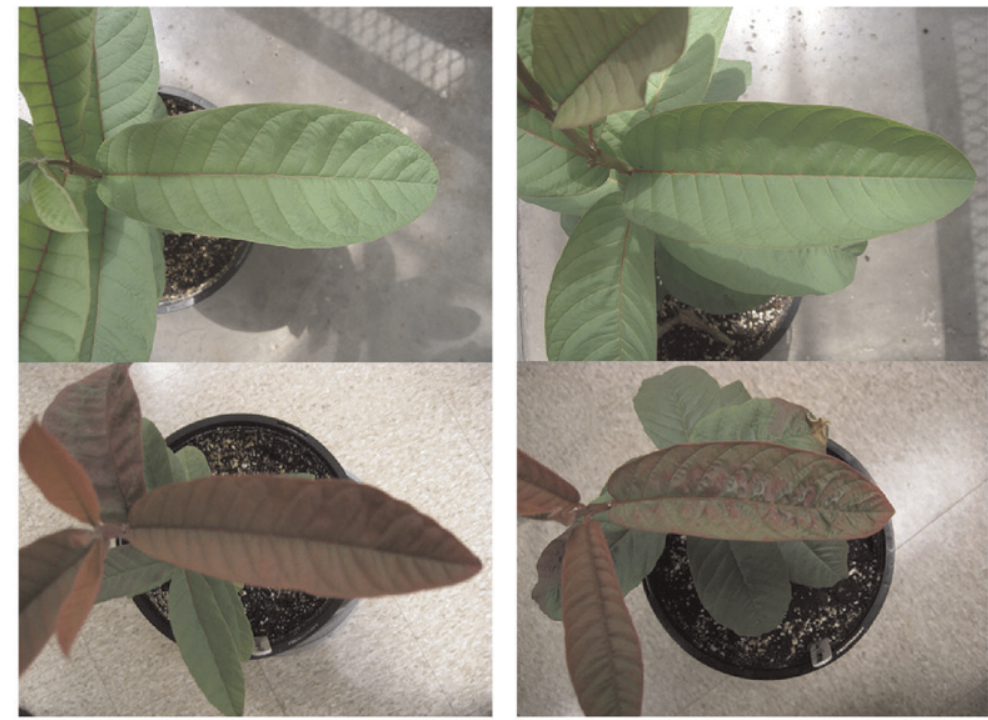

B

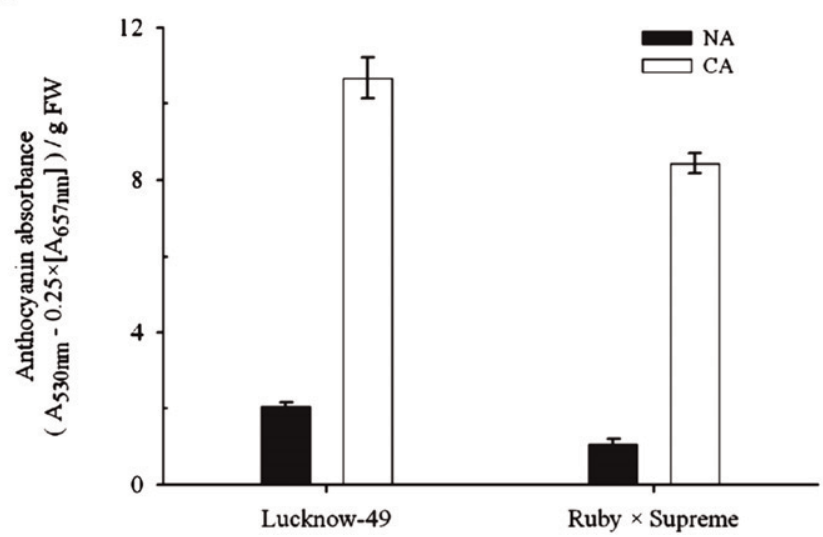

Fig. 2. (A) Changes in leaf color and (B) leaf relative anthocyanin content of Psidium guajava L. 'Lucknow-49' and 'Ruby $\times$ Supreme' in nonacclimation (NA) and cold acclimation (CA) regimes. Values are means $\pm \mathrm{SE}$ of three replicates.

treatment temperatures, but the cultivar difference was smaller compared with the nonacclimated plants of both cultivars (compare Figs. $3 \mathrm{~A}$ and $3 \mathrm{~B}$ ). Both nonacclimated and cold-acclimated 'Ruby $\times$ Supreme' showed less freezing injury than 'Lucknow-49' at 13 of 14 temperatures used in freeze-thaw tests and therefore was more freezing-tolerant.

$\mathrm{LT}_{50}$, as a measurement of freezing tolerance, was derived for nonacclimated and cold-acclimated cultivars by determining the temperature corresponding to the midpoint between the maximum and minimum injury (Fig. 4). For nonacclimated plants, $\mathrm{LT}_{50} \mathrm{~S}$ were -2.3 and $-2.7^{\circ} \mathrm{C}$ for 'Lucknow49' and 'Ruby $\times$ Supreme', respectively. After CA, leaf $\mathrm{LT}_{50} \mathrm{~S}$ decreased in both cultivars to -4.2 and $-4.6{ }^{\circ} \mathrm{C}$ for 'Lucknow$49^{\prime}$ and 'Ruby $\times$ Supreme', respectively (Table 1). Thus, LFT of both cultivars (assessed as $\mathrm{LT}_{50}$ ) increased after CA by at least $1.9^{\circ} \mathrm{C}$, which was obtained by the end of the $10 / 5^{\circ} \mathrm{C}$ (day/night) step of the CA regime with no further gain in freezing tolerance achieved after $7 / 3{ }^{\circ} \mathrm{C}$ (day/night) exposure for an additional week (data not shown).
Protein alterations during cold acclimation. Coomassie-stained SDS-PAGE profiles of total proteins and their antidehydrin immunoblots for 'Lucknow-49' and 'Ruby $x$ Supreme' are presented in Figure 5AB. The SDS-PAGE profile (Fig. 5A) indicated that four of these proteins, with molecular weights of $69,48,23.5$, and $17.4 \mathrm{kDa}$, accumulated in cold-acclimated leaf tissue from both cultivars. The extent of accumulation of these proteins (on SDS-PAGE) differed among cultivars; however, all four bands accumulated at a relatively higher level in 'Lucknow-49' than in 'Ruby $\times$ Supreme' (Fig. 5C). The levels of three proteins, with molecular weights of 65,59 , and $22 \mathrm{kDa}$, appeared to be reduced after CA in both cultivars with relatively greater reduction in 'Lucknow-49'.

Antidehydrin immunoblots of the leaf proteins revealed differing levels of accumulation of two dehydrins in nonacclimated and cold-acclimated plants (Fig. 5B). A $17.4 \mathrm{kDa}$ dehydrin was present at high levels in the cold-acclimated tissues but for some unexplained reasons was not detected on the immunoblots of nonacclimated samples for both cultivars. Levels of the $17.4 \mathrm{kDa}$ dehydrin in cold-acclimated leaves from 'Lucknow-49' appeared visually to be substantially higher than from 'Ruby $\times$ Supreme'. Another low-accumulation-level dehydrin $(48 \mathrm{kDa})$ was detected in both nonacclimated and cold-acclimated leaves from the two guava cultivars with a relatively higher level in 'Lucknow-49' (Fig. 5B). Neither of these dehydrins was detected in parallel samples probed with preimmune serum (data not shown). Curiously, both bands detected as dehydrins were visible only faintly on the SDS-PAGE protein gels (Fig. 5A-B). The reason for the apparent lower dehydrin intensities on SDS-PAGE is not clear. However, other reports showed similar low intensities of particularly leaf dehydrins on the SDSPGAE profiles from woody plants (Lim et al., 1999).

Leaf water potential and protein alterations during drought stress. Plants experienced reduced water potential from -0.44 $\mathrm{MPa}$ (control) to -1.4 and $-1.55 \mathrm{MPa}$ (fully stressed) for 'Lucknow-49' and 'Ruby $\times$ Supreme', respectively, when continually exposed to drought stress (Fig. 6). 'Lucknow-49' apparently exhibited more drought resistance than 'Ruby $\times$ Supreme' because it required more time to become droughtstressed as indicated by the loss in turgor and leaf water potential: 20 and $18 \mathrm{~d}$ of water deficit for 'Lucknow-49' and 'Ruby $\times$ Supreme', respectively. When watering was resumed to the control level for $2 \mathrm{~d}$, the leaf water potential of stressed plants almost fully recovered in both cultivars (Fig. 6).

SDS-PAGE profiles of leaf proteins and their antidehydrin immunoblots for 'Lucknow-49' and 'Ruby $\times$ Supreme' for control, drought-stressed, and recovered plants are presented in Figure 7A-B. Various protein bands were observed to undergo quantitative changes after drought stress but reverted to the control level after recovery (Fig. 7A). Two of these proteins, with molecular weights of 17.4 and $16 \mathrm{kDa}$, accumulated in leaf tissue of drought-stressed plants in 'Lucknow-49', but no such change could be detected in 'Ruby $\times$ Supreme', at least from SDS- PAGE profiles (Fig. 7C). The levels of the 102 and $34 \mathrm{kDa}$ proteins reduced after drought stress and then reversed approximately to the control levels in recovered plants in both cultivars.

Antidehydrin immunoblots revealed that the $17.4 \mathrm{kDa}$ dehydrin was present in the fully drought-stressed plants, whereas it was undetected in both control and recovered plants for both cultivars. The level of the $17.4 \mathrm{kDa}$ dehydrin was relatively higher in 'Ruby $x$ Supreme' than 'Lucknow-49'. Once again, this dehydrin appeared as a faint band on the Coomassie-stained gel.

\section{Discussion}

The results presented here provide information on the physiological responses of guava to freezing stress and CA. We investigated 


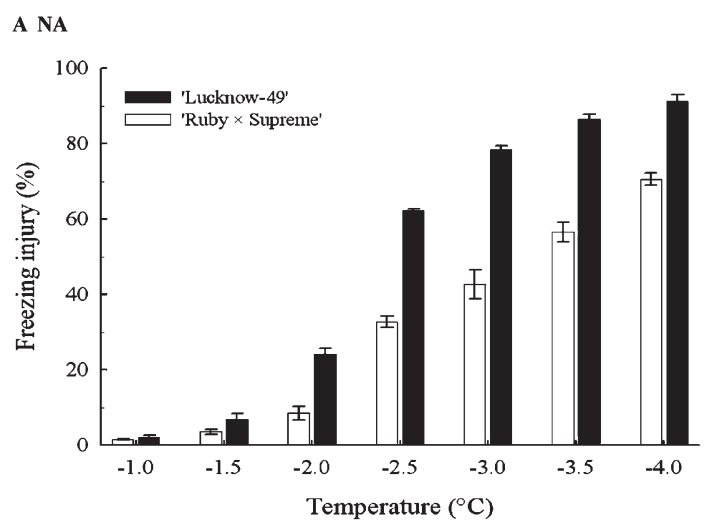

B CA

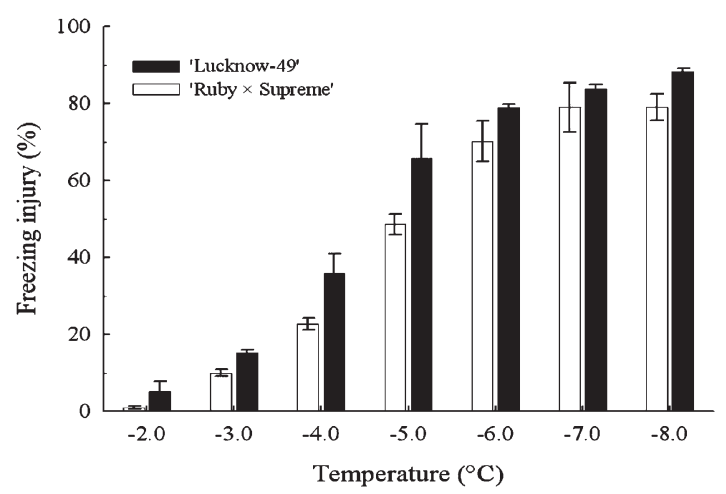

Fig. 3. Leaf percentage freezing injury measured at different freezing treatment temperatures in Psidium guajava L. 'Lucknow-49' and 'Ruby $\times$ Supreme' in (A) nonacclimation (NA) and (B) cold acclimation (CA) regimes. Vertical bars represent means \pm SE of three samples.

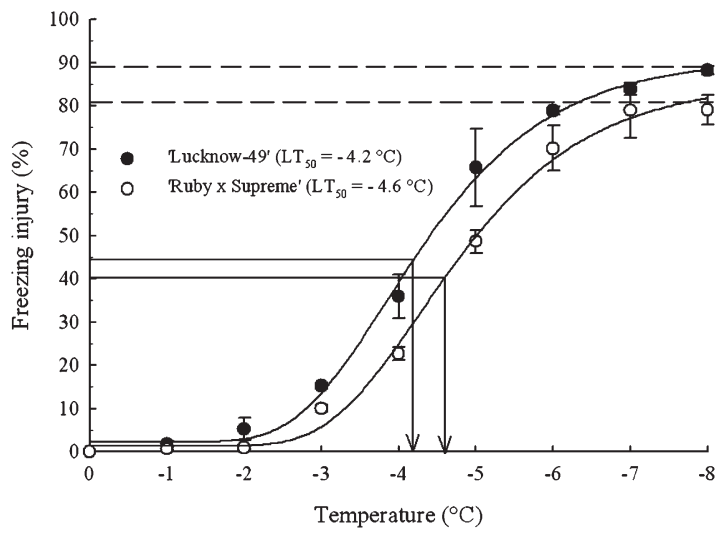

Fig. 4. Leaf freezing tolerance $\left(\mathrm{LT}_{50}\right)$ of cold-acclimated Psidium guajava $\mathrm{L}$. 'Lucknow-49' and 'Ruby $\times$ Supreme'. Dotted lines show the maximum percent injury. Arrows show the $\mathrm{LT}_{50}$ values. Percent injury at $\mathrm{LT}_{50}=\left(\%\right.$ injury $_{\max }+\%$ injury $\left.\min _{n}\right) / 2$, where $\%$ injury $_{\max }=$ the maximum percent injury and $\%$ injury $_{\min }=$ the minimum percent injury $(=0)$. Values are means $\pm \mathrm{SE}$ of three replicates.

the ability of guava leaves to tolerate freezing stress and exhibit CA. We also studied coldinduced changes in growth, relative water content, total proteins, and anthocyanin contents and the overlapping responses to cold and drought stresses.

\section{Nonacclimated and cold-acclimated leaf freezing tolerance}

There are very limited data in the literature on the cold tolerance of members of the Mytaceae family to which guava belongs. However, Tibbits et al. (1991) showed that leaves of Eucalyptus cordata Labill. and Eucalyptus gunnii Hook.f. can tolerate frost down to $\approx-3{ }^{\circ} \mathrm{C}$ and to lower than $-15{ }^{\circ} \mathrm{C}$, respectively, when subjected to artificial freezing, whereas, according to Morton (1987b), Feijoa sellowiana O.Berg can withstand temperatures as low as $-10{ }^{\circ} \mathrm{C}$. Ours is the first laboratory study on freezing tolerance and CA in guava. Our $\mathrm{LT}_{50}$ data indicate that guava leaves accrued freezing tolerance to a maximum of $-2.7^{\circ} \mathrm{C}$ at nonacclimated state (Table 1); however, actual LFT at respective subfreezing temperatures varied
Table 1. Leaf tissue freezing tolece $\left(\mathrm{LT}_{50}\right)$ of Psidium guajava L. 'Lucknow-49' and 'Ruby $\times$ Supreme' at nonacclimation (NA) and 28-d cold acclimation (CA) regimes.

\begin{tabular}{lcc}
\hline & \multicolumn{2}{c}{$\operatorname{LT}_{50}\left({ }^{\circ} \mathrm{C}\right)$} \\
\cline { 2 - 3 } Cultivar & $\mathrm{NA}$ & $\mathrm{CA}$ \\
\hline Lucknow-49 & $-2.3 \mathrm{a}^{\mathrm{z}}$ & $-4.2 \mathrm{~b}$ \\
Ruby $\times$ Supreme & $-2.7 \mathrm{a}$ & $-4.6 \mathrm{~b}$ \\
\hline
\end{tabular}

${ }^{\mathrm{z}}$ Means followed by different letters are significantly different at $P \leq 0.05$ according to the two-way analysis of variance.

significantly between the two cultivars (Fig. $3 \mathrm{~A})$. Both cultivars also exhibited CA ability as evidenced by increased LFT (at various subfreezing temperatures) and a gain of $\approx 2{ }^{\circ} \mathrm{C}$ in $\mathrm{LT}_{50}$ in response to a $\mathrm{CA}$ regime (Fig. 3B; Table 1).

$\mathrm{LT}_{50}$, estimated by electrolyte leakage, has been widely used as a parameter defining the freezing tolerance of plant tissues. Based on this parameter, however, the leaf tissue of 'Lucknow-49' and 'Ruby $\times$ Supreme' did not show a significant difference in LFT (Table 1). In contrast, when comparing percent freezing injury of the two cultivars at various subfreezing treatment temperatures, 'Ruby $\times$ Supreme' exhibited significantly less injury than 'Lucknow-49' at all test temperatures for nonacclimated plants and at most temperatures for cold-acclimated tissues (Fig. 3A-B). For example, nonacclimated 'Lucknow-49' had almost twice the percentage injury at $-3.5^{\circ} \mathrm{C}$ and 1.5 -fold injury at $-4{ }^{\circ} \mathrm{C}$ compared with 'Ruby $\times$ Supreme' (Fig. 3A). This contrast was maintained even after $\mathrm{CA}$ because, at -4 and $-5{ }^{\circ} \mathrm{C}$, 'Ruby $\times$ Supreme' suffered only $\approx 75 \%$ injury of that in 'Lucknow-49' (Fig. 3B). These data indicate that 'Ruby $\times$ Supreme' had greater LFT than 'Lucknow-49' and suggest that the $\mathrm{LT}_{50}$ alone may not be a comprehensive parameter to discern small but significant differences in LFTs of the two cultivars used in this study.

Gradual exposure to increasing stresses may induce physiological adjustments that protect plants from injury after abrupt environmental stresses. It has been suggested that to obtain proper freezing tolerance and reach maximum tolerance, temperatures may need to be changed in sequence (Weiser, 1970). Moreover, if a plant cannot adjust cellular processes for proper function during longterm exposure to low, nonfreezing temperatures, it probably has reached its maximal freezing tolerance. Yadava (1996) suggested that the optimal growth temperature for guava is $\approx 20$ to $30{ }^{\circ} \mathrm{C}$. Therefore, in the present study, the final CA temperatures were approached gradually starting from $18 / 12{ }^{\circ} \mathrm{C}$ (day/night) to stepwise cooler temperatures instead of abruptly exposing plants to $4{ }^{\circ} \mathrm{C}$ (or lower), a widely used protocol in the literature. We also noted that freezing tolerance of guava leaf tissue did not further increase after exposure to $7 / 3{ }^{\circ} \mathrm{C}$ (day/night) for an additional week compared with the LFT levels attained after $10 / 5{ }^{\circ} \mathrm{C}$ (day/night) exposure (data not shown). This study provides, for the 
A
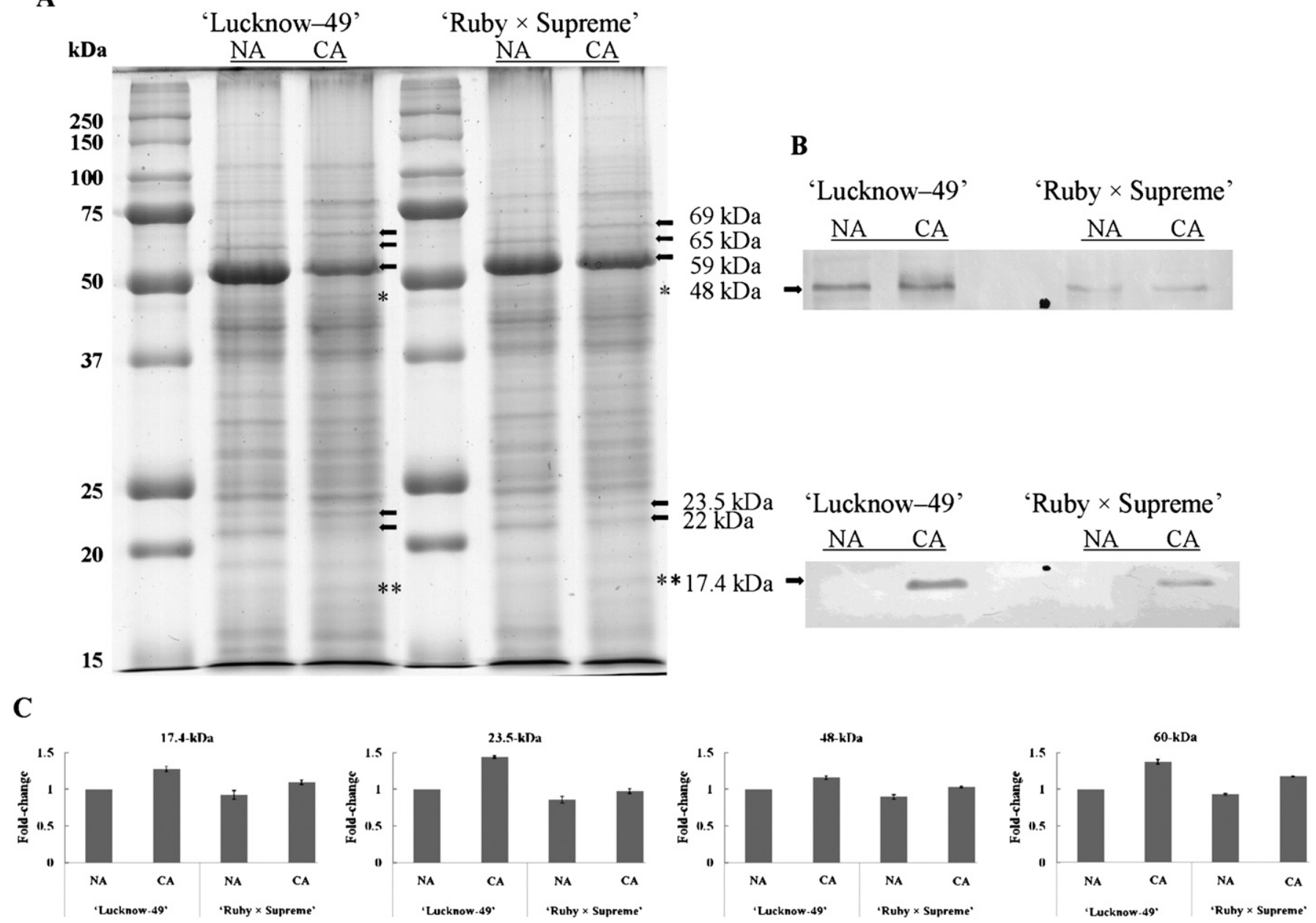

Fig. 5. (A) SDS-PAGE profiles (12 $\mu \mathrm{g}$ protein per lane) and (B) antidehydrin immunoblotting ( $4 \mu \mathrm{g}$ protein per lane) of total soluble proteins from leaves of Psidium guajava L. 'Lucknow-49' and 'Ruby $\times$ Supreme' in nonacclimation (NA) and cold acclimation (CA) regimes. Asterisk (*) indicates the $48 \mathrm{kDa}$ band and the double asterisk (**) indicates the $17.4 \mathrm{kDa}$ band. (C) Comparisons of relative changes in levels of polypeptides bands $(69,48,23.5$, and $17.4 \mathrm{kDa})$ for each cultivar in NA and CA regimes. Data were derived from densitometric scans of gels presented in A, where 'Lucknow-49' at the NA regime was given a value " 1 ". Values are means \pm SE of three replicates.

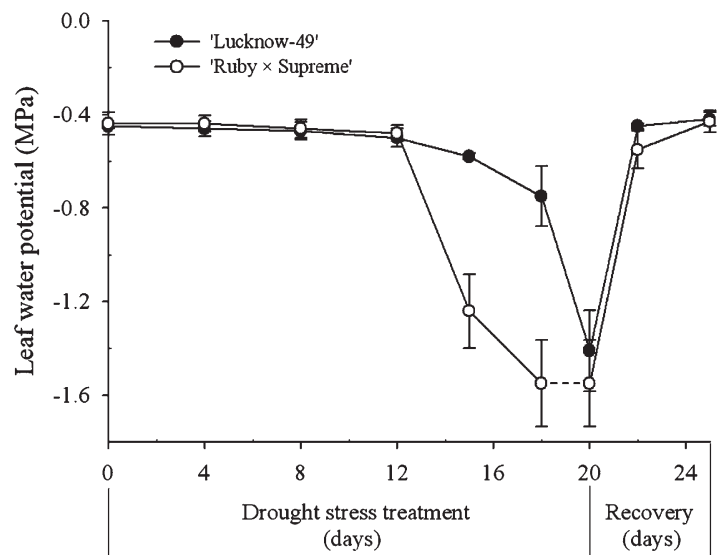

Fig. 6. Leaf water potential ( $\left.\Psi_{\text {leaf }}, \mathrm{MPa}\right)$ of Psidium guajava L. 'Lucknow-49' and 'Ruby $\times$ Supreme' under $20-\mathrm{d}$ and $18-\mathrm{d}$ drought stress treatment, respectively, and during recovery. Recovery period started from 20 th day of drought stress and lasted for $5 \mathrm{~d}$ for both cultivars. Dotted line (for 'Ruby $x$ Supreme') shows the period between the last measurements made on 18th day of drought treatment and the resumption of watering on 20th day. Values are means \pm SE of four replicates.

first time, an environmentally controlled CA protocol for guava as follows: $18 / 12{ }^{\circ} \mathrm{C}$ (day/ night) for 1 week, then $15 / 9{ }^{\circ} \mathrm{C}$ (day/night) for 1 week, and $10 / 5^{\circ} \mathrm{C}$ (day/night) for 1 week.

\section{Physiological changes during} cold acclimation

Growth. Comparison of structural components or metabolites from nonacclimated and cold-acclimated plants is a common way to investigate the biochemical basis of freezing tolerance (Xin and Browse, 2000). We observed reduced shoot elongation of guava plants that were subjected to the $\mathrm{CA}$ regime (Fig. 1A). CA involves a reduction or cessation of growth in many plants. In temperate woody plants, growth cessation is closely associated with the onset of CA (Pellett, 1998). Low temperature had a negative effect on the growth of poplar, which may be the result of the mobilization of carbohydrates for a putative cryoprotective process (Renaut et al., 2004). In addition, reduction of photosynthesis is also considered a cause for growth reduction in Hydrangea species during CA (Pagter et al., 2008). However, here, whether the observed reduction of shoot elongation could be considered a mechanism for guava to cope with low temperatures or if it was only a stress response to unfavorable conditions is unknown.

Leaf water content. The water status of a plant tissue usually reflects the potential degree of freezing injury incurred by the plant. Because the freeze-induced injury is primarily the result of the cellular dehydration 


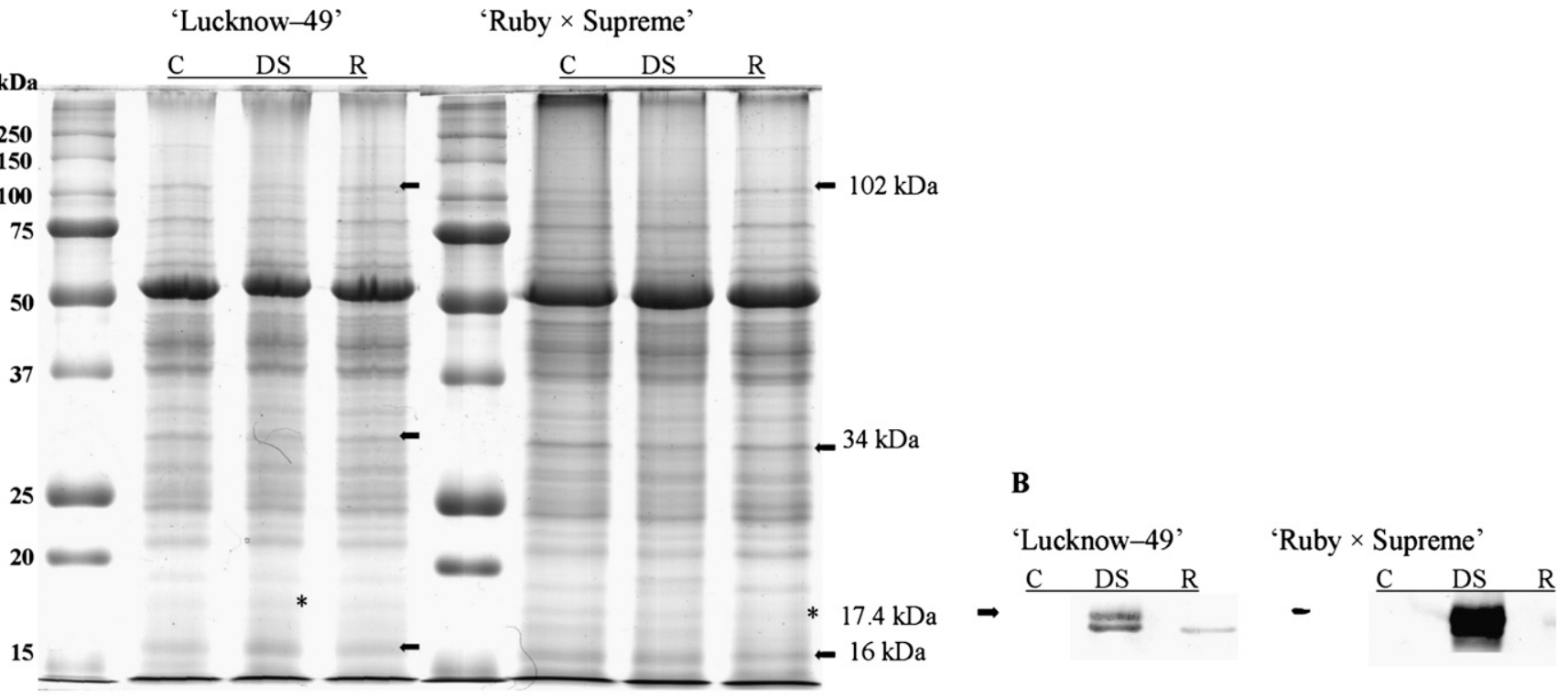

C
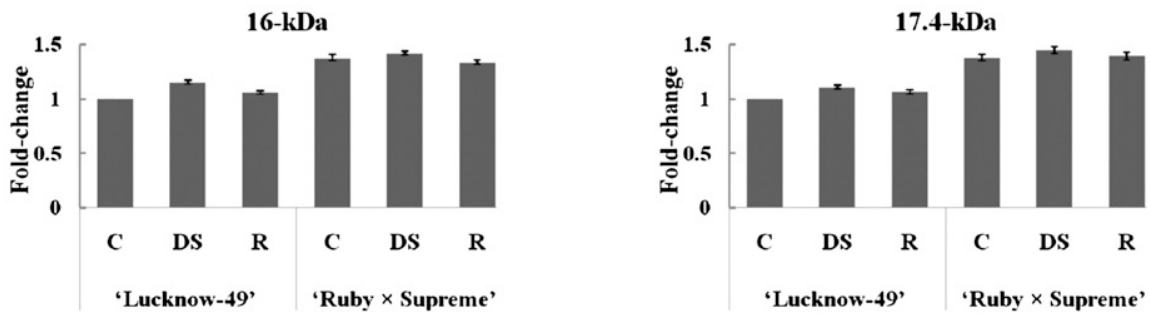

Fig. 7. (A) SDS-PAGE profiles ( $15 \mu \mathrm{g}$ protein per lane) and (B) antidehydrin immunoblotting ( $6 \mu \mathrm{g}$ protein per lane) of total soluble proteins from leaves of Psidium guajava L. 'Lucknow-49' and 'Ruby $\times$ Supreme' from control (C), drought-stressed (DS), and recovered (R) plants. Control leaves were collected before plants were subjected to drought stress treatment. Drought-stressed plants were subjected to water deficit for 20 and $18 \mathrm{~d}$ for 'Lucknow-49' and 'Ruby $\times$ Supreme', respectively. Recovered plants were watered well for $5 \mathrm{~d}$ after the 20 -d drought stress for both cultivars. Asterisk (*) indicates the $17.4 \mathrm{kDa}$ band. (C) Comparisons of relative changes in levels of polypeptides bands (17.4 and $16 \mathrm{kDa})$ from C, DS, and R plants in each cultivar. Data were derived from densitometric scans of gels presented in A, where 'Lucknow-49' control was given a value "1". Values are means \pm SE of three replicates.

associated with freezing (Thomashow, 1999; Xin and Browse, 2000; Wisniewski and Arora, 1992), tissues with a large amount of free water are expected to be more susceptible to freezing injury and the CA process is expected to involve reduction in cellular water content. Our data indicated that the leaf relative water content of guava decreased after CA (Fig. 1B), which is consistent with prior reports showing the reduction in tissue water content during CA in woody plants. The water content of the lateral buds of Betula pendula Roth decreased from spring to fall (Li et al., 2003). Additionally, short-day/low-temperature treatments lowered the leaf water content in silver birch (Li et al., 2002) and Rhododendron L. (Marian et al., 2004). 'Ruby $\times$ Supreme' showed relatively higher levels of leaf relative water content than 'Lucknow-49' in both NA and $\mathrm{CA}$ regimes, suggesting that 'Ruby $\times$ Supreme' may be more sensitive to freezing stress than 'Lucknow-49'. However, concerning the opposite conclusion from the comparisons of percent freezing injury at different treatment temperatures showing that leaves of 'Ruby $\times$ Supreme' were indeed more freezing tolerant than 'Lucknow-49', it appears that CA response of guava genotypes may be somewhat different from those for temperate zone woody perennials in terms of the rela- tionship between freezing tolerance and water status of tissues. On the other hand, greater adaptability of 'Ruby $\times$ Supreme' for the reduction of leaf water content than 'Lucknow-49' in response to CA conditions (Fig. 1B) appears to be congruent with observed greater LFT of cold-acclimated 'Ruby $\times$ Supreme'.

Leaf anthocyanins. CA is associated with the synthesis and accumulation of metabolites such as pigments, carbohydrates, and compatible solutes (Renaut et al., 2004). Accumulation of anthocyanins (water-soluble pigments) was observed in leaves of guava after CA in this study (Fig. 2A-B). This is consistent with previous studies indicating that anthocyanin accumulation in green leaves and stems is mainly induced by environmental stresses such as low temperatures and high light. A twofold accumulation of anthocyanins was observed in winter oilseed rape leaves grown in low temperatures for 3 weeks, which was hypothesized to act as a filter that shielded the mesophyll from excessive radiation (Solecka et al., 1999). Krol et al. (1995) believed that anthocyanins protect the mesophyll of young Pinus banksiana Lamb. seedlings from low-temperature photoinhibition. Additionally, anthocyanins also function as antioxidants, helping maintain toxic reactive oxygen species at low steadystate levels in plants exposed to cold stress (Pennycooke et al., 2005). Therefore, it is conceivable that enhanced freezing tolerance of cold-acclimated guava leaves may partly be associated with increased antioxidant system and photo-oxidation prevention from induced anthocyanins. Moreover, anthocyanin accumulation, particularly in young expanding guava leaves during CA (Fig. 2A), may be the result of more protection from photoinhibitory damage required by younger leaves.

Leaf proteins. CA of plants also involves the synthesis and accumulation of protective proteins (Thomashow, 1999). Although both qualitative and quantitative changes in protein content have been reported during $\mathrm{CA}$ in various woody perennials, research on tropical fruit trees is limited.

Our results indicate that the guava leaves exhibited protein accumulation during CA. Four polypeptides $(69,48,23.5$, and 17.4 $\mathrm{kDa}$ ) were found to accumulate in response to CA (Figs. 5A and C), which may be the result of increased protein synthesis and/or decreased turnover. It is interesting to obtain almost identical leaf protein profiles (SDSPAGE) among the two guava genotypes in this study (Fig. 5A); however, two-dimensional 
gel electrophoresis may still reveal subtle differences. The function of these proteins remains unknown; however, two proteins (48 and $17.4 \mathrm{kDa}$ ) were identified as dehydrinlike proteins in both cultivars (Fig. 5B). Dehydrin proteins are known to accumulate during CA in woody plants, including bark, buds, and leaves (Arora et al., 1996, 1997; Arora and Wisniewski, 1994; Lim et al., 1999). Arora and Wisniewski (1994) noted that more frost-hardy deciduous peach bark tissue accumulated higher levels of dehydrins than the less hardy evergreen ones. However, the level of dehydrin (48 and $17.4 \mathrm{kDa}$ ) accumulation did not coincide with the LFT among guava genotypes. The more freezingtolerant 'Ruby $\times$ Supreme' (Fig. 3A-B), accumulated relatively lower levels of dehydrins than 'Lucknow-49' during CA (Fig. 5B-C), indicating the multifactorial character of cold hardiness at the molecular level.

Common responses to cold and drought stresses. Plants may exhibit partly overlapping responses to freezing and drought stress because freeze-induced injury in plants is mainly the result of cellular dehydration (Xin and Browse, 2000). This logic suggests that proteins accumulating in response to water stress could be involved in the mechanisms of CA (Guy et al., 1992). Comparison of proteins expressed in cold-acclimated and drought-stressed leaves indicated one common dehydrin $(17.4 \mathrm{kDa})$ in both cultivars of guava (Figs. 5B and 7B). This result implies that the accumulation of the $17.4 \mathrm{kDa}$ dehydrin is triggered by dehydration in response to drought or low temperatures and further indicates that responses to $\mathrm{CA}$ and drought stress may involve common mechanisms in guava. Additionally, guava plants became drought-stressed (wilting) only after at least $18 \mathrm{~d}$ of water deficit (Fig. 6), indicating that it possesses significant drought tolerance, an observation supported by earlier reports (Morton, 1987a; Yadava, 1996).

In summary, this study demonstrates that 'Lucknow-49' and 'Ruby $\times$ Supreme' guava cultivars possess LFT of $\approx-2.5^{\circ} \mathrm{C}$ (as assessed by a laboratory freeze-thaw tests) and are able to increase this tolerance by $\approx 2{ }^{\circ} \mathrm{C}$ after a temperature-controlled cold acclimation regime. Moreover, LFT at individual freezing treatment temperatures varied between 'Lucknow-49' and 'Ruby $\times$ Supreme' at nonacclimated and cold-acclimated states with the latter cultivar being significantly more freeze-tolerant when compared up to $-4{ }^{\circ} \mathrm{C}$ for nonacclimated and up to $-8{ }^{\circ} \mathrm{C}$ for cold-acclimated tissues. It appears that diverse mechanisms such as growth and leaf water content reductions, anthocyanin accumulation, and stress protein turnover (specifically dehydrins) may contribute to guava's ability to tolerate freezing stress. CA in guava appears to be a multifactorial process involving complex physiological and biochemical changes and also overlapping responses with drought stress. More studies are warranted to explore potential variability in freezing tolerance and CA potential of a diverse array of guava cultivars and tissues (stem, buds, roots, and so on) to help develop cold-tolerant cultivars.

\section{Literature Cited}

Arora, R. and J.P. Palta. 1991. A loss in plasmamembrane ATPase activity and its recovery coincides with incipient freeze-thaw injury and post-thaw recovery in onion bulb scale tissue. Plant Physiol. 95:846-852.

Arora, R., L.J. Rowland, and G.R. Panta. 1997. Chill-responsive dehydrins in blueberry: Are they associated with cold hardiness or dormancy transitions? Physiol. Plant. 101:8-16.

Arora, R. and M.E. Wisniewski. 1994. Cold acclimation in genetically related (sibling) deciduous and evergreen peach (Prunus persica [L.] Batsch) II. A 60-kilodalton bark protein in cold-acclimated tissues of peach is heat stable and related to the dehydrin family of proteins. Plant Physiol. 105:95-101.

Arora, R., M.E. Wisniewski, and L.J. Rowland. 1996. Cold acclimation and alterations in dehydrin-like and bark storage proteins in the leaves of sibling deciduous and evergreen peach (Prunus persica [L.] Batsch). J. Amer. Soc. Hort. Sci. 121:915-919.

Arora, R., M.E. Wisniewski, and R. Scorza. 1992. Cold acclimation in genetically related (sibling) deciduous and evergreen peach (Prunus persica [L.] Batsch). I. Seasonal changes in cold hardiness and polypeptides of bark and xylem tissues. Plant Physiol. 99:15621568.

Bassett, C.L., M. Wisniewski, T.S. Artlip, J.L. Norelli, J. Renaut, and R.E. Farrell, Jr. 2006. Global analysis of genes regulated by low temperature and photoperiod in peach bark. J. Amer. Soc. Hort. Sci. 131:551-563.

Boyer, J.S. 1982. Plant productivity and environment. Science 218:443-448.

Close, T.J. 1997. Dehydrins: A commonality in the response of plants to dehydration and low temperatures. Physiol. Plant. 100:291-296.

Close, T.J., R.D. Fenton, and F. Moonan. 1993. A view of plant dehydrins using antibodies specific to the carboxy terminal peptide. Plant Mol. Biol. 23:279-286.

Danyluk, J., A. Perron, M. Houde, A. Limin, B. Fowler, N. Benhamou, and F. Sarhan. 1998. Accumulation of an acidic dehydrin in the vicinity of the plasma membrane during cold acclimation of wheat. Plant Cell 10:623-638.

Esen, A. 1978. A simple method for quantitative, semiquantitative, and qualitative assay of protein. Anal. Biochem. 89:264-273.

Gaspar, M.M., R.B. Ferreira, M.M. Chaves, and A.R. Teixeira. 1997. Improved method for the extraction of proteins from Eucalyptus leaves. Application in leaf response to temperature. Phytochem. Anal. 8:279-285.

Guy, C.L. and D. Haskell. 1988. Detection of polypeptides associated with the cold acclimation process in spinach. Electrophoresis 9:787796.

Guy, C.L., D. Haskell, L. Neven, P. Klein, and C. Smelser. 1992. Hydration-state-responsive proteins link cold and drought stress in spinach. Planta 188:265-270.

Hawaii Agricultural Statistics Service. 1999. Statistics of Hawaii fruits and nuts: Guavas. 13 Feb. 2008. <http://www.nass.usda.gov/hi/fruit/ xgua9.pdf $>$.

Kleine, T., P. Kindgren, C. Benedict, L. Hendrickson, and A. Strand. 2007. Genome-wide gene expression analysis reveals a critical role for CRYPTOCHROME1 in the response of Arabi- dopsis to high irradiance. Plant Physiol. 144:1391-1406.

Krol, M., G.R. Gray, V.M. Hurry, G. Oquist, L. Malek, and N.P.A. Huner. 1995. Low-temperature stress and photoperiod affect an increased tolerance to photoinhibition in Pinus banksiana seedlings. Can. J. Bot. 73:1119-1127.

Levitt, J. 1980. Response of plants to environmental stresses: Vol. 1. Chilling, freezing and high temperature stresses. 2nd Ed. Academic Press, New York, NY.

Li, C., T. Puhakainen, A. Welling, A. ViheraAarnio, A. Ernstsen, O. Junttila, P. Heino, and E.T. Palva. 2002. Cold acclimation in silver birch (Betula pendula). Development of freezing tolerance in different tissues and climatic ecotypes. Physiol. Plant. 116:478-488.

Li, C., A. Vihera-Aarnio, T. Puhakainen, O. Junttila, P. Heino, and E.T. Palva. 2003. Ecotypedependent control of growth, dormancy and freezing tolerance under seasonal changes in Betula pendula Roth. Trees (Berl.) 17:127132.

Lim, C.C., S.L. Krebs, and R. Arora. 1999. A $25-$ $\mathrm{kDa}$ dehydrin associated with genotype- and age-dependent leaf freezing-tolerance in Rhododendron: A genetic marker for cold hardiness? Theor. Appl. Genet. 99:912-920.

Lim, C.C., E.C. Townsend, and R. Arora. 1998 Comparing Gompertz and Richards function to estimate freezing injury in Rhododendron using electrolyte leakage. J. Amer. Soc. Hort. Sci. 123:246-252.

Marian, C.O., A. Eris, S.L. Krebs, and R. Arora. 2004. Environmental regulation of a $25 \mathrm{kDa}$ dehydrin in relation to Rhododendron cold acclimation. J. Amer. Soc. Hort. Sci. 129:354 359.

Morton, J.F. 1987a. Guava: Psidium guajava L., p. 356-363. In: Fruits of warm climates. Florida Flair Books, Miami, FL.

Morton, J.F. 1987b. Feijoa, p. 367-370. In: Fruits of warm climates. Florida Flair Books, Miami, FL.

Muthalif, M.M. and L.J. Rowland. 1994. Identification of dehydrin-like proteins responsive to chilling in floral buds of blueberry (Vaccinium, section Cyanococcus). Plant Physiol. 104: 1439-1447.

Neff, M.M. and J. Chory. 1998. Genetic interaction between phytochrome A, phytochrome B, and cryptochrome 1 during Arabidopsis development. Plant Physiol. 118:27-36.

Pagter, M., C.R. Jensen, K.K. Petersen, F. Liu, and R. Arora. 2008. Changes in carbohydrates, $\mathrm{ABA}$ and bark proteins during seasonal cold acclimation and deacclimation in Hydrangea species differing in cold hardiness. Physiol. Plant. 134:473-485.

Palta, J.P., J. Levitt, and E.J. Stadelmann. 1977. Freezing injury in onion bulb cells. I. Evaluation of the conductivity method and analysis of ion and sugar efflux from injured cells. Plant Physiol. 60:393-397.

Pellett, H. 1998. Breeding of cold hardy woody landscape plants, p. 317-324. In: Li, P.H. and T.H.H. Chen (eds.). Plant cold hardiness. Molecular biology, biochemistry and physiology. Plenum Press, New York, NY.

Peng, Y., W. Lin, W. Cai, and R. Arora. 2007. Overexpression of a Panax ginseng tonoplast aquaporin alters salt tolerance, drought tolerance and cold acclimation ability in transgenic Arabidopsis plants. Planta 226:729-740.

Peng, Y., J.L. Reyes, H. Wei, Y. Yang, D. Karlson, A.A. Covarrubias, S.L. Krebs, A. Fessehaie, and R. Arora. 2008. RcDhn5, a cold acclimation-responsive dehydrin from Rhododendron 
catawbiense rescues enzyme activity from dehydration effects in vitro and enhances freezing tolerance in RcDhn5-overexpressing Arabidopsis plants. Physiol. Plant. 134:583-597.

Pennycooke, J.C., S. Cox, and C. Stushnoff. 2005. Relationship of cold acclimation, total phenolic content and antioxidant capacity with chilling tolerance in petunia (Petunia $\times$ hybrida). Environ. Exp. Bot. 53:225-232.

Renaut, J., S. Lutts, L. Hoffmann, and J.F. Hausman. 2004. Response of poplar to chilling temperatures: Proteomic and physiological aspects. Plant Biol. 6:81-90.

Rinne, P., P. Kaicuranta, L.H. van der Plas, and C. van der Schoot. 1999. Dehydrins in coldacclimated apices of birch (Betula pubescens Ehrh.): Production, localization and potential role in rescuing enzyme function during dehydration. Planta 209:377-388.

Solecka, D., A.M. Boudet, and A. Kacperska. 1999. Phenylpropanoid and anthocyanin changes in low-temperature treated winter oilseed rape leaves. Plant Physiol. Biochem. 37:491-496.
Steponkus, P.L. 1984. Role of the plasma membrane in freezing injury and cold acclimation. Annu. Rev. Plant Physiol. 35:543584.

Sutinen, M.-L., J.P. Palta, and P.B. Reich. 1992. Seasonal differences in freezing stress resistance of needles of Pinus nigra and Pinus resinosa: Evaluation of the electrolyte leakage method. Tree Physiol. 11:241-254.

Thomashow, M.F. 1999. Plant cold acclimation: Freezing tolerance genes and regulatory mechanisms. Annu. Rev. Plant Physiol. Plant Mol. Biol. 50:571-599.

Tibbits, W.N., B.M. Potts, and M.H. Savva. 1991. Inheritance of freezing resistance in interspecific $\mathrm{F}_{1}$ hybrids of Eucalyptus. Theor. Appl. Genet. 83:126-135.

Weiser, C.J. 1970. Cold resistance and injury in woody plants. Science 169:1269-1278.

Wisniewski, M., C. Bassett, and L.V. Gusta. 2003. An overview of cold hardiness in woody plants Seeing the forest through the trees. HortScience 38:952-959.
Wisniewski, M. and R. Arora. 1992. Response of fruit trees to cold temperatures, p. 299-320. In: Biggs A.R. (ed.). Handbook of cytology, histology and histochemistry of fruit tree diseases.. CRC Press, Inc, Boca Raton, FL.

Wisniewski, M., T.J. Close, T. Artlip, and R. Arora 1996. Seasonal patterns of dehydrins and 70$\mathrm{kDa}$ heat-shock proteins in bark tissue of eight species of woody plants. Physiol. Plant. 96: 496-505.

Wisniewski, M., R. Webb, R. Balsamo, T.J. Close, X. Yu, and M. Griffith. 1999. Purification, immunolocalization, cryoprotective, and antifreeze activity of PCA60: A dehydrin from peach (Prunus persica). Physiol. Plant. 105: 600-608.

Xin, Z. and J. Browse. 2000. Cold comfort farm: The acclimation of plants to freezing temperatures. Plant Cell Environ. 23:893-902.

Yadava, U.L. 1996. Guava (Psidium guajava L.): An exotic tree fruit with potential in the southeastern United States. HortScience 31: 789-794. 